\title{
Antioxidant activities of $B$. campestris var. chinensis and $B$. juncea L. Czern var. Laciniata Makino baby leaf extracts
}

\author{
Hee-Yeon Kwon ${ }^{1}$, Su-Mi Lee ${ }^{1}$, Sun-Il Choi ${ }^{1}$, Bong-Yeon Cho ${ }^{1}$, Seung-Hyun Choi ${ }^{1}$, \\ Wan-Sup Sim ${ }^{1}$, Han Xionggao ${ }^{1}$, Gill-Woong Jang ${ }^{1}$, Ok-Hwan Lee ${ }^{1}$, Duck-Hwan Park ${ }^{2 *}$ \\ ${ }^{1}$ Department of Food Science and Biotechnology, Kangwon National University, Chuncheon 24341, Korea \\ ${ }^{2}$ Applied Biology Program, Division of Bioresource Sciences, Kangwon National University, Chuncheon 24341, Korea
}

\section{청경채 및 경수채 어린잎 추출물의 항산화활성}

\author{
권희연 ${ }^{1} \cdot$ 이수미 $^{1} \cdot$ 최선일 $^{1} \cdot$ 조봉연 ${ }^{1} \cdot$ 최승현 $^{1} \cdot$ 심완섭 $^{1} \cdot$ 한웅호 $^{1} \cdot$ 장길웅 $^{1} \cdot$ 이옥환 $^{1} \cdot$ 박덕환 $^{2 *}$ \\ 1강원대학교 바이오산업공학부 식품생명공학전공, ${ }^{2}$ 강원대학교 생물자원과학부 응용생물학전공
}

\begin{abstract}
The purpose of this study was to investigate antioxidant activities of $B$. campestris var. chinensis and $B$. juncea L. Czem var. Laciniata Makino baby leaf extract. We studied DPPH radical scavenging activity, ABTS radical scavenging activity, feric ion reducing antioxidant power (FRAP), total phenol contents, the total chlorophylls contents, total carotenoid contents and oxygen radical absorbance capacity (ORAC). Our results showed that antioxidant activities (DPPH radical scavenging activity, ABTS radical scavenging activity, FRAP) of the B. campestris var. chinensis baby leaf extract were significantly increased in a dose-dependent manner. Also, these baby leaf extracts had the highest total chlorophyll and carotenoid contents $(9.26 \pm 0.09 \mu \mathrm{g} / \mathrm{mL}$ and $1.62 \pm 0.01 \mu \mathrm{g} / \mathrm{mL})$. However, B. juncea L. Czern var. Laciniata Makino baby leaf extract showed higher in total phenol content (15.92 $\pm 0.29 \mathrm{mg}$ GAE/g) and ORAC value $(987.18 \mu \mathrm{M} \mathrm{TE} / \mathrm{g})$ than those $(14.66 \pm 0.11 \mathrm{mg} \mathrm{GAE} / \mathrm{g}$ and $928.39 \mu \mathrm{M} \mathrm{TE} / \mathrm{g})$ of $B$. campestris var. chinensis baby leaf extract. Our study provide a basic data for the development of functional foods using two kinds of sprouts by analyzing the antioxidant and physiological activities of these extracts. These results suggest that functional foods can be developed using two kinds of baby leaf.
\end{abstract}

Key words : B. campestris var. chinensis baby leaf, B. juncea L. Czem var. Laciniata Makino baby leaf, antioxidant activity

\section{서 론}

현대사회의 소득수준 향상으로 인해 풍족한 삶을 누리고 있으나, 이에 따른 식생활의 변화로 비만을 비롯한 각종 질환이 증가하고 있고, 고령화 인구의 증가에 따라 향상된 삶에 대한 요구가 증가되고 있는 추세이다(1). 인간은 생명 을 유지하기 위하여 호흡을 해야만 한다. 이 과정에서 약

*Corresponding author. E-mail : dhp@kangwon.ac.kr Phone : 82-33-250-6432, Fax : 82-33-259-5558

Received 25 January 2019; Revised 19 March 2019; Accepted 25 March 2019.

Copyright (c) The Korean Society of Food Preservation. All rights reserved.
$2 \%$ 의 활성산소가 발생하고(2), 이러한 활성산소는 체내에 이물질이 침투했을 때 방어적인 역할을 하는 것으로 알려져 있다. 하지만 활성산소의 생성되는 속도가 제거되는 속도 보다 빨라질 경우, 오히려 체내 불균형으로 인한 부작용으 로 다양한 질병을 초래할 수 있다(3). 과다하게 생성된 활성 산소는 정상 세포막과 세포를 손상시키며(4), 고지혈증, 동 맥경화, 뇌졸중 등의 신경성 질환 및 백내장, 당뇨병 등의 질병을 야기한다 $(5,6)$. 피부를 구성하는 콜라겐을 산화시켜 노화를 촉진시키게 되어 스트레스에 대처하는 능력이 감소 하며 항상성을 유지하지 못하게 되며 질병에 걸리는 위험이 증가하게 된다(7). 체내에서 생성된 활성산소뿐만 아니라 환경오염, 스트레스 등의 외부 요인에 의해 발생한 활성 산소가 더해질 수 있으므로(8), 체내 활성산소에 대한 관리 
가 중요하고 여겨진다. 현재까지 개발된 항산화제의 종류 로는 tocopherol, carotenoid, 아미노산류, flavonoids, tannin, ascorbic acid, phenolic compound 및 셀레늄 등의 천연 항산 화제와 tert-butylated hydroxytoluene (BHT), tert-butylated hydroxyanisol (BHA), tert-butyl hydroquinone 등의 합성 항 산화제가 존재한다. 하지만 이러한 합성 항산화제는 독성 및 발암유발 등의 부작용 등의 문제들로 인해 식품 이용에 제한되어지고 있다 $(9,10)$. 이에 비해 천연 항산화제들은 인 체에 작용 하였을 때 부작용을 초래하지 않는 것으로 알려 져 있으나 합성 항산화제에 비해 체내 항산화 작용력이 낮아, 안전하고 항산화 작용이 뛰어난 천연 항산화제의 연 구 개발이 필요한 실정이다(11). 이에 따라 최근 천연 식물 소재에 함유되어 있는 다양한 기능을 가진 소재들을 항산화 제 원료로 이용하려는 연구가 활발하게 이루어지고 있다.

십자화과(Brassicaceae)는 십자가 형태로 4개의 꽃잎이 있으며 영양 성분이 많이 포함되어 있다. 또한 씨앗에 싹이 튼 후 약 일주일 후에 야채의 새싹 채소가 새싹이 나며 새싹 채소의 비타민 및 미네랄 함유량은 완전 재배 야채의 3-4 배이고, 청경채(B. campestris var. chinensis) 및 경수채 (B. juncea L. Czern var. Laciniata Makino)는 Brassicaceae에 속하는 대표적인 작물 중 하나이다(12).

청경채는 현재 전 세계적으로 섭취되고 있는 작물이며, 비타민 C, 비타민 A, $\beta$-카로틴 및 칼슘, 칼륨, 나트륨과 같은 다양한 미네랄을 함유하고 있으며 경수채는 다양한 미네랄과 비타민 $\mathrm{A}$, 비타민 $\mathrm{C}$, 비타민 $\mathrm{E}, \beta$-카로틴을 함유하 고 있다고 보고된 바 있다(13). 그러나, 이러한 다양한 영양 소를 가졌음에도 불구하고 청경채와 경수채 어린잎 채소에 대한 성분 분석 및 항산화 활성을 측정한 연구는 제대로 이루어지고 있지 않은 실정이다.

따라서, 본 연구진들은 2 종의 십자화과 채소인 청경채와 경수채 어린잎으로 두 가지 채소에 대한의 항산화 활성 및 성분을 비교분석하여, 추후 이들을 이용한 기능성 식품 개발을 위한 기초 자료를 제공하고자 연구를 수행하였다.

\section{재료 및 방법}

\section{실험재료 및 시약}

본 연구에 사용한 청경채(B. campestris var. chinensis)와 경수채(B. juncea L. Czern var. Laciniata Makino) 어린잎은 (주)참농원(Goseong, Gangwon)에서 제 공받았으며 어린잎 원 물을 동결건조한 후 분말화하여 시료무게의 50 배의 $80 \%$ ethanol을 가하여 상온에서 24 시간 추출 후 2 번의 여과, 감 압농축을 거친 후 동결건조 하였다. 청경채와 경수채 어린 잎 추출물은 일정 농도로 희석하여 실험에 사용하였다. 본 실험에 사용된 2,2-diphenyl-1-picrylhydrazyl (DPPH), 2,2' -azobis(2-methylpropionamidine) dihydrochloride (AAPH),
2,4,6-tripyridyl-s-triazine(TPTZ), ascorbic acid 등은 SigmaAldrich Co.Ltd (St. Louis, MO, USA)로부터 구입하여 사용 하였다.

\section{$\mathrm{DPPH}$ 라디칼 소거활성}

2,2-diphenyl-1-picrylhydrazyl (DPPH) 라디칼 소거활성 측정은 $\mathrm{Kim}$ 등(14)의 방법을 참고하여 측정하였다. DW를 사용하여 농도별로 희석한 시료 $0.2 \mathrm{~mL}$ 에 $0.4 \mathrm{mM} \mathrm{DPPH}$ 용액(용매 ethanol) $0.8 \mathrm{~mL}$ 를 첨가하여 혼합한 후 상온에서 10 분간 반응하였다. 그 후 microplate reader (Spectramax i3, Molecular Devices, Sunnyvale, CA, USA)를 사용하여 $517 \mathrm{~nm}$ 에서 흡광도 값을 측정한 후 다음 식을 이용하여 계산하였다. 양성대조군으로는 ascorbic acid를 사용하였다.

$$
\mathrm{DPPH} \text { 라디칼 소거활성 }(\%)=\left\{1-\left\lceil\frac{A_{\text {Experiment }}}{A_{\text {control }}}\right\rceil\right\} \times 100
$$

\section{ABTS 라디칼 소거활성}

2,2'-azino-bis(3-ethylbenzothiazoline-6-sulphonic acid) (ABTS) 라디칼 소거활성 측정은 $\operatorname{Re}$ 등(15)의 방법을 참고 하여 측정하였다. ABTS 라디칼 소거활성 실험의 시료는 $\mathrm{DW}$ 로 농도별로 희석하여 사용하였다. $7 \mathrm{mM} \mathrm{ABTS}$ 와 2.45 $\mathrm{mM}$ potassium persulfate 용액을 암소에서 16시간 동안 반응 시켜서 라디칼을 발생시킨 후 96-well microplate에 시료 $10 \mu \mathrm{L}$ 을 가하고 $\mathrm{ABTS}$ 용액 $290 \mu \mathrm{L}$ 를 가하여 혼합한 후 암소에서 6분간 반응시켰다. 반응이 끝난 반응액은 $734 \mathrm{~nm}$ 에서 흡광도를 측정한 후, 아래의 식에 의해 라디칼 소거활 성을 계산하였다. 양성대조군으로는 ascorbic acid를 사용 하였다.

$$
\mathrm{ABTS} \text { 라디칼 소거활성 }(\%)=\left\{1-\left\lceil\frac{A_{\text {Experiment }}}{A_{\text {control }}}\right\rceil\right\} \times 100
$$

\section{$\mathrm{FRAP}$ 활성 측정}

Ferric ion reducing antioxidant power (FRAP) 활성은 Benzie 등(16)의 방법을 참고하여 측정하였다. Sodium acetate $\left(\mathrm{C}_{2} \mathrm{H}_{3} \mathrm{NaO}_{2}\right)$ 와 acetic $\operatorname{acid}\left(\mathrm{C}_{2} \mathrm{H}_{4} \mathrm{O}_{2}\right)$ 를 혼합하여 sodium acetate buffer ( $\mathrm{pH}$ 3.6)를 만들고, $40 \mathrm{mM} \mathrm{HCl}$ 과 TPTZ(2,4,6-tripyridyl-s-triazine)를 혼합하여 $10 \mathrm{mM}$ TPTZ solution을 만든다. 실험을 위한 반응용액은 sodium acetate buffer (pH 3.6), $10 \mathrm{mM}$ TPTZ(2,4,6-tripyridyl-s- triazine) 및 $20 \mathrm{mM} \mathrm{FeCl} \cdot 6 \mathrm{H}_{2} \mathrm{O}$ 를 $10: 1: 1$ 의 비율로 혼합하여 만들어 사용하였다. 조제한 용액 $1.5 \mathrm{~mL}$ 과 $\mathrm{DW}$ 를 사용하여 농도별 로 희석한 시료 $50 \mu \mathrm{L}, \mathrm{DW} 150 \mu \mathrm{L}$ 를 혼합한 후 $37^{\circ} \mathrm{C}$ 에서 4 분간 반응 시킨 후 $593 \mathrm{~nm}$ 에서 흡광도를 측정하였다.

\section{총 페놀 함량 측정}

총 페놀의 함량은 Folin-Ciocalteu 방법(17)의 방법을 참 
고하여 측정하였다. $\mathrm{DW}$ 로 농도별로 희석한 시료 $1 \mathrm{~mL}$ 과 $10 \%$ Folin-Ciocalteu 시약 $1 \mathrm{~mL}$ 혼합하고 $2 \% \mathrm{Na}_{2} \mathrm{CO}_{3}$ 시약을 $1 \mathrm{~mL}$ 첨가하여 혼합한 후 암소에서 1 시간 동안 반응시킨 후 $750 \mathrm{~nm}$ 에서 흡광도를 측정하였다. 총 페놀 함량은 gallic $\mathrm{acid}$ 를 이용하여 검량곡선을 작성하여 계산하였다.

\section{총 클로로필 함량과 총 카로티노이드 함량 측정}

클로로필 $\mathrm{a}$, 클로로필 b, 총 카로티노이드는 Wellburn의 메탄올 추출 방법(18)을 이용하여 다음과 같이 측정하였다. 샘플 $1 \mathrm{~g}$ 을 $100 \%$ methanol $50 \mathrm{~mL}$ 과 혼합한 후 1 분 동안 $1,000 \mathrm{rpm}$ 으로 섞어준다. 그 후, $3,000 \mathrm{rpm}$ 으로 5 분간 원심 분리 후 상층액을 채취하여 $470 \mathrm{~nm}, 652 \mathrm{~nm}, 665 \mathrm{~nm}$ 에서 각각 측정한 후 다음의 계산식을 이용하여 구하였다.

Chlorophyll a $(\mathrm{mg} / \mathrm{mL})=16.72 \times$ O.D $_{665}-9.16 \times$ O.D $_{652}$ Chlorophyll b $(\mathrm{mg} / \mathrm{mL})=34.09 \times$ O.D $_{665}-15.28 \times$ O.D $_{652}$ Total chlorophyll $(\mathrm{mg} / \mathrm{mL})=$ Chlorophyll $\mathrm{a}+$ Chlorophyll $\mathrm{b}$ Total carotenoid $(\mathrm{mg} / \mathrm{mL})=\left(1,000 \times 0 . D_{470}-1.63 \times\right.$

Chlorophyll a $-104.96 \times$ Chlorophyll b)/221

\section{ORAC 지수 측정}

Oxygen radical absorbance capacity (ORAC) 지수 측정은 $\mathrm{Ou}$ 등(19)의 방법을 참고하여 측정하였다. 시료는 $75 \mathrm{mM}$ sodium phosphate buffer (pH 7.4)를 이용하여 농도별로 희석 하여 사용하였다. Black 96-well microplate에 시료 $25 \mu \mathrm{L}$, $40 \mathrm{nM}$ fluorescein $150 \mu \mathrm{L}$ 을 첨가하고 측정 직전에 $150 \mathrm{mM}$ AAPH $25 \mu \mathrm{L}$ 을 첨가한 후 microplate spectrofluorometer (Spectramax GEMINI-XSPenIII 667MHzRam6f4printer: $\mathrm{HP} 895 \mathrm{C}$ )를 이용하여 $485 \mathrm{~nm}, 530 \mathrm{~nm}$ 에서 $37^{\circ} \mathrm{C}$ 에서 90 분간 3 분마다 fluorescence의 감소 정도를 측정하였다. 결과 값은 시료 첨가군와 무 첨가군의 Area Under Curve(AUC) 값을 나타낸 후, 표준물질인 Trolox를 이용하여 표준 검량 곡선 에 대입하여 나타내었다.

Area under curve $(\mathrm{AUC})=1+\mathrm{f}_{1} / \mathrm{f}_{0}+\mathrm{f}_{2} / \mathrm{f}_{0}+\mathrm{f}_{3} / \mathrm{f}_{0}+4 / \mathrm{f}_{0}+\ldots \mathrm{f} / 31 / \mathrm{f}_{0}$

\section{통계처리}

$\mathrm{DPPH}$ 라디칼 소거활성, $\mathrm{ABTS}$ 라디칼 소거활성, FRAP (Ferric ion reducing antioxidant power) 활성, Total phenolic content, Total chlorophyll content, Total carotenoid content, ORAC 지수 결과 값의 통계처리는 SAS version 9.4 (SAS institute Inc., Cary, NC, USA)을 이용하여 분석하였다. 유의 성 분석은 one-way ANOVA 검정을 실시하였으며 Duncan 의 다중범위 검정법(Duncan's multiple range test)으로 유의 성은 $\mathrm{p}<0.05$ 수준에서 검정하였다.

\section{결과 및 고찰}

\section{$\mathrm{DPPH}$ 라디칼 소거활성}

$\mathrm{DPPH}$ 는 항산화 능력을 측정하는데 있어 대표적인 반응 물질로 그 자체로 매우 안정한 자유 라디칼이며 DPPH 라디 칼 소거활성은 하이드록시 라디칼(-OH)을 갖는 페놀성 화 합물이나 플라보노이드를 가진 물질에서 수소공여를 통한 라디칼의 소거로 자색 화합물이 노란색으로 탈색되는 원리 는 이용하는 방법이다(20). 청경채와 경수채 어린잎 추출물 의 $\mathrm{DPPH}$ 라디칼의 소거활성을 확인한 결과는 Fig. 1 과 같다.

양성대조군으로 사용한 ascorbic acid의 DPPH 라디칼 소 거활성은 $25,50,100 \mu \mathrm{g} / \mathrm{mL}$ 농도에서 $52.41 \%-97.71 \%$ 의 소거활성이 나타났으며, 청경채 어린잎 추출물의 $\mathrm{DPPH}$ 라디칼 소거활성은 $1,5,10 \mathrm{mg} / \mathrm{mL}$ 농도에서 $45.47 \%=95.90 \%$, 경수채 어린잎 추출물의 DPPH 라디칼 소거활성은 1,5 , $10 \mathrm{mg} / \mathrm{mL}$ 농도에서 $47.37 \%-93.35 \%$ 의 소거활성이 나타났 다. 본 실험의 결과에서 청경채와 경수채 어린잎 추출물 모두 수소공여를 통한 DPPH 라디칼 소거활성이 농도 의존 적으로 증가하는 것을 확인하였다. 십자화과 채소중 하나 인 자색 콜라비 추출물을 이용하여 항산화 활성을 측정한 Yang 등(21)의 연구에 따르면 십자화과 채소의 뛰어난 $\mathrm{DPPH}$ 라디칼 소거활성을 확인 할 수 있었으며 본 연구에서 의 결과와 유사함을 확인할 수 있었다.

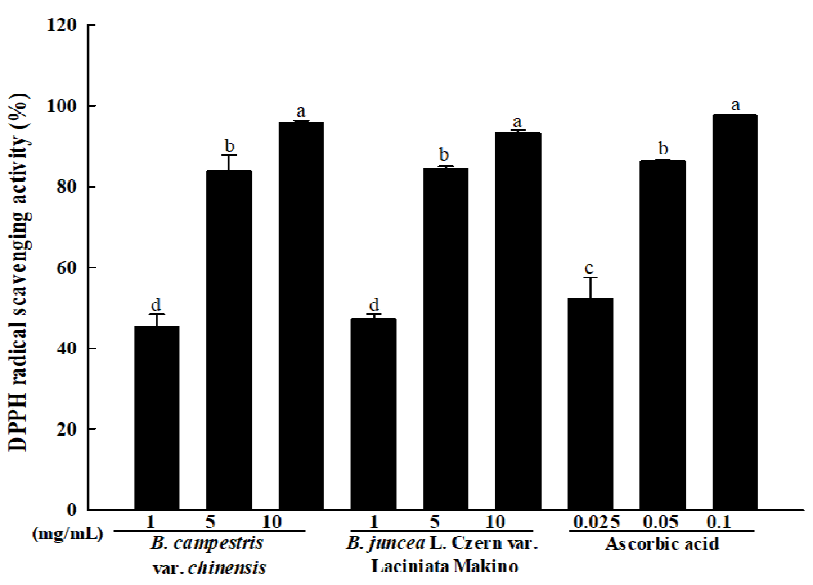

Fig. 1. DPPH radical scavenging activity of various concentrations Brassica spp. baby leaf extract.

Values are mean $\pm \mathrm{SD}(\mathrm{n}=3)$. Means (bar value) not sharing a common letter $(\mathrm{a}-\mathrm{d})$ are significantly different $(\mathrm{p}<0.05)$.

\section{ABTS 라디칼의 소거활성}

ABTS 라디칼을 이용한 항산화능의 측정은 potassium persulfate와의 반응에 의해 생성되는 ABTS free 라디칼이 샘플 내의 항산화 물질에 의해 제거되어 라디칼의 청록색이 탈색되는 것을 이용한 방법이다(22). 청경채와 경수채 어린 잎 추출물의 $\mathrm{ABTS}$ 라디칼의 소거활성을 확인한 결과는 Fig. 2와 같다. 양성대조군으로 사용한 ascorbic acid의 
$\mathrm{ABTS}$ 라디칼 소거활성은 $25,50,100 \mu \mathrm{g} / \mathrm{mL}$ 농도에서 9.98\%-20.31\%의 소거활성이 나타났으며, 청경채 어린잎 추출물의 $\mathrm{ABTS}$ 라디칼 소거활성은 $1,5,10 \mathrm{mg} / \mathrm{mL}$ 농도에 서 $11.81 \%-45.42 \%$, 경수채 어린잎 추출물의 ABTS 라디칼 소거활성은 $1,5,10 \mathrm{mg} / \mathrm{mL}$ 농도에서 $12.09 \%-48.95 \%$ 의 소 거활성이 나타났다. 본 실험의 결과에서 청경채와 경수채 어린잎 추출물 내의 항산화 물질에 의해 ABTS free 라디칼 이 제거되면서 농도 의존적으로 항산화 활성이 증가하는 것임을 확인하였다. 본 실험의 결과, 같은 십자화과 채소에 속하는 배추의 $\mathrm{ABTS}$ 라디칼 소거활성을 측정한 Hwang 과 $\operatorname{Kim}$ (23)의 연구에서 보고한 실험 결과와 유사하게 청경 채와 경수채 어린잎 추출물에서도 농도 의존적으로 $\mathrm{ABTS}$ 라디칼 소거활성이 증가하는 것을 확인하였다.

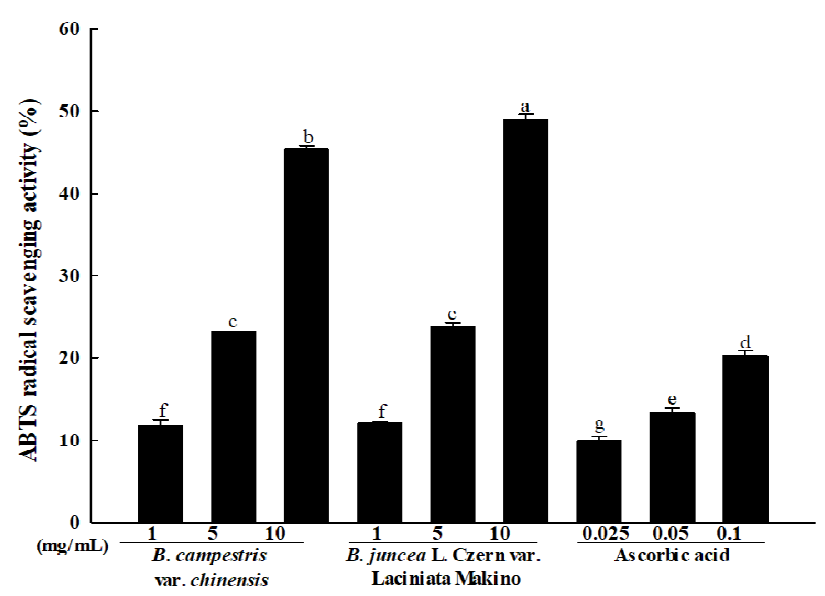

Fig. 2. ABTS radical scavenging activity of various concentrations Brassica spp. baby leaf extract.

Values are mean $\pm \mathrm{SD}(\mathrm{n}=3)$. Means (bar value) not sharing a common letter (a-g) are significantly different $(\mathrm{p}<0.05)$.

\section{FRAP 활성}

FRAP assay는 colored ferrous tripyridyl triazine complex 에 의해 ferric ion이 ferrous로 전환되는 과정을 분석함으로 써 항산화력을 측정하는 방법으로 낮은 $\mathrm{pH}$ 에서 환원제에 의해 ferric tripyridyltriazine ( $\mathrm{Fe}^{3+}$-TPTZ) 복합체가 ferrous tripyridyltriazine $\left(\mathrm{Fe}^{2+}-\mathrm{TPTZ}\right)$ 으로 환원되는 원리를 이용한 것이다(24). FRAP assay에서 흡광도 수치는 그 자체가 시료 의 환원력을 나타내며, 높은 항산화 활성을 가질수록 흡광 도의 수치가 높게 나타난다. 청경채와 경수채 어린잎 추출 물을 이용하여 FRAP assay에 의한 항산화 활성을 측정한 결과는 Fig. 3와 같다. 양성대조군으로 사용한 ascorbic acid 의 FRAP assay에 의한 항산화 활성은 $0.125,0.25,0.5$ $\mathrm{mg} / \mathrm{mL}$ 농도에서 $0.65-2.27$ 의 흡광도 값을 나타내었으며, 청경채 어린잎 추출물의 항산화 활성은 $1,5,10 \mathrm{mg} / \mathrm{mL}$ 농도에서 0.21-1.07, 경수채 어린잎 추출물에서는 $1,5,10$ $\mathrm{mg} / \mathrm{mL}$ 농도에서 0.19-1.04의 흡광도 값을 나타내어 청경채 와 경수채 어린잎 추출물 모두에서 농도 의존적으로 환원력
이 높아져 항산화 활성이 증가한 것을 확인하였다. 또한, 같은 십자화과 채소중 하나인 녹색 및 자색 콜라비의 착즙 액으로 항산화 활성을 측정한 $\mathrm{Kim}$ 등(25)의 연구에 따르면 녹색 및 자색 콜라비의 착즙액에서 농도 유의적으로 FRAP 활성이 증가함을 확인할 수 있었으며 본 연구에서의 실험결 과와 유사함을 확인하였다.

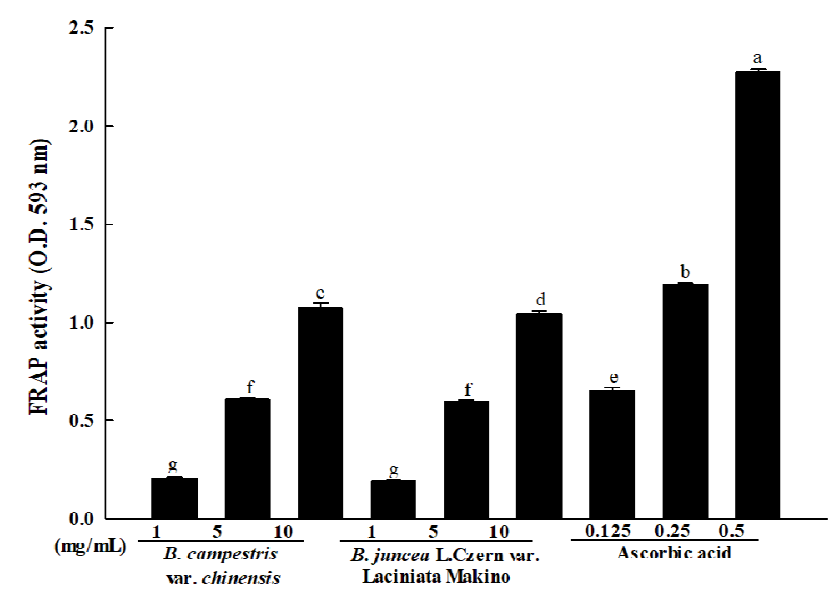

Fig. 3. FRAP activity of various concentrations Brassica spp. baby leaf extract.

Values are mean $\pm S D(n=3)$. Means (bar value) not sharing a common letter ( $\mathrm{a}-\mathrm{g})$ are significantly different $(\mathrm{p}<0.05)$.

총 페놀 함량

총 페놀함량 측정은 다양한 페놀성 물질들이 FolinCiocalteu 시약의 phosphomolybdic acid에 전자를 공여하여 청자색을 띄는 환원물을 생성하는 원리를 이용한 방법이다 (26). 청경채와 경수채 어린잎 추출물을 이용한 총 페놀 함량 측정 실험의 결과는 Table 1 과 같다. 총 페놀 함량은 각각 $14.66 \pm 0.11,15.92 \pm 0.29 \mathrm{mg} \mathrm{GAE} / \mathrm{g}$ 으로 측정되었고, 경수채 어린잎 추출물이 약 $1.28 \mathrm{mg} \mathrm{GAE} / \mathrm{g}$ 더 함유된 것으 로 확인되었다. 페놀류 화합물들의 함량이 높아질수록 항 산화 활성이 높아진다는 Chen과 Yen (27)의 연구 결과에 따라, 페놀함량에 따른 항산화 활성에 있어서 경수채 어린 잎 추출물이 청경채 어린잎 추출물보다 더 뛰어남을 확인하 였다. 또한, 같은 십자화과 채소 중 하나인 브로콜리의 total phenolic content를 측정한 Koh 등(28)의 연구에서 브로콜리

Table 1. Total phenolic contents of Brassica spp. baby leaf extract

\begin{tabular}{ccc}
\hline Sample & $\begin{array}{c}\text { Total phenolic contents } \\
\left(\mathrm{mg} \mathrm{GAE}^{1} / \mathrm{g}\right)\end{array}$ & $\mathrm{RSD}^{2)}$ \\
\hline B. campestris var. chinensis & $14.66 \pm 0.11^{3)}$ & 0.75 \\
\hline B. juncea L. Czern var. Laciniata Makino & $15.92 \pm 0.29^{*}$ & 1.84 \\
\hline
\end{tabular}

${ }^{1)}$ GAE:gallic acid equivalent

${ }^{2)} \mathrm{RSD}$ : relative standard deviation

${ }^{3}$ )Values are mean $\pm \mathrm{SD}(\mathrm{n}=3)$. Data were statistically analyzed by independent sample t-test. *Values are significantly different between $B$. campestris var. chinensis and $B$. juncea L. Czern var. Laciniata Makino $(\mathrm{p}<0.05)$. 
의 total phenol 함량이 6-10 mg/g이라고 보고한 바, 청경채 와 경수채의 total phenol의 함량은 브로콜리보다 높으며 이에 따라 청경채와 경수채의 페놀 함량에 따른 항산화 활성이 더 우수함을 확인하였다.

\section{총 클로로필 및 총 카로티노이드 함량}

총 클로로필 함량과 총 카로티노이드 함량 측정은 클로 로필과 카로티노이드가 무기용매에는 녹지 않고 유기용매 에만 녹는 성질을 이용한 실험이다. 청경채와 경수채 어린 잎 추출물을 이용한 총 클로로필과 총 카로티노이드 측정 실험의 결과는 Table 2 와 같다. 청경채 어린잎 추출물의 클로로필 a의 함량은 $6.53 \pm 0.03 \mathrm{\mu g} / \mathrm{mL}$ 이였고 클로로필 $\mathrm{b}$ 의 함량은 $2.72 \pm 0.07 \mu \mathrm{g} / \mathrm{mL}$ 로 총 클로로필 함량은 $9.26 \pm 0.09 \mu \mathrm{gg} / \mathrm{mL}$ 로 측정되었다. 경수채 어린잎 추출물의 클로로필 $\mathrm{a}$ 의 함량은 $4.63 \pm 0.03 \mathrm{\mu g} / \mathrm{mL}$, 클로로필 $\mathrm{b}$ 의 함량 은 $1.85 \pm 0.08 \mu \mathrm{g} / \mathrm{mL}$ 로 총 클로로필 함량은 $6.48 \pm 0.11 \mu \mathrm{g} / \mathrm{mL}$ 로 측정되었다. 따라서 청경채 어린잎 추출물의 총 클로로 필 함량이 약 $2.78 \mathrm{\mu g} / \mathrm{mL}$ 정도 많이 함유된 것으로 확인이 되었다. 청경채와 경수채 어린잎 추출물의 총 카로티노이 드 함량은 $1.62 \pm 0.01 \mathrm{\mu g} / \mathrm{mL}, 1.09 \pm 0.02 \mu \mathrm{g} / \mathrm{mL}$ 로 청경채 어 린잎 추출물의 카로티노이드 함량이 약 $0.53 \mu \mathrm{g} / \mathrm{mL}$ 많이 함유된 것으로 확인이 되었다. 클로로필의 함량이 높을수 록 세균 생육 저지, 상처 치료, 간기능 증진작용 등 다양한 생리활성을 돕는다고 보고한 Lee 등(29)의 연구와 카로티 노이드는 생체 내 피부노화나 심혈관계 질환 등 여러 가지 생리활성을 돕는다고 보고한 $\mathrm{Ha}$ 등(30)의 연구에 따르면 청경채 어린잎 추출물의 총 클로로필과 총 카로티노이드 함량이 경수채 어린잎 추출물보다 더 많으므로 클로로필과 카로티노이드에 따른 생리활성은 청경채 어린잎 추출물이 경수채 어린잎 추출물보다 우수할 것으로 사료된다.
ORAC 지수를 측정한 결과 각각 $928.4 \pm 17.7,987.2 \pm 20.3$ $\mu$ mole TE/g의 값을 나타내어 경수채 어린잎 추출물이 약 1.06 배 높은 값은 나타내어 항산화능이 더 우수함을 확인할 수 있었다. 또한, 페놀 함량과 ORAC 값이 밀접한 관계가 있다고 보고한 Park과 Hong (32)의 연구 결과와 본 연구에 서의 페놀함량과 ORAC 값의 상관관계가 일치함을 확인하 였다.

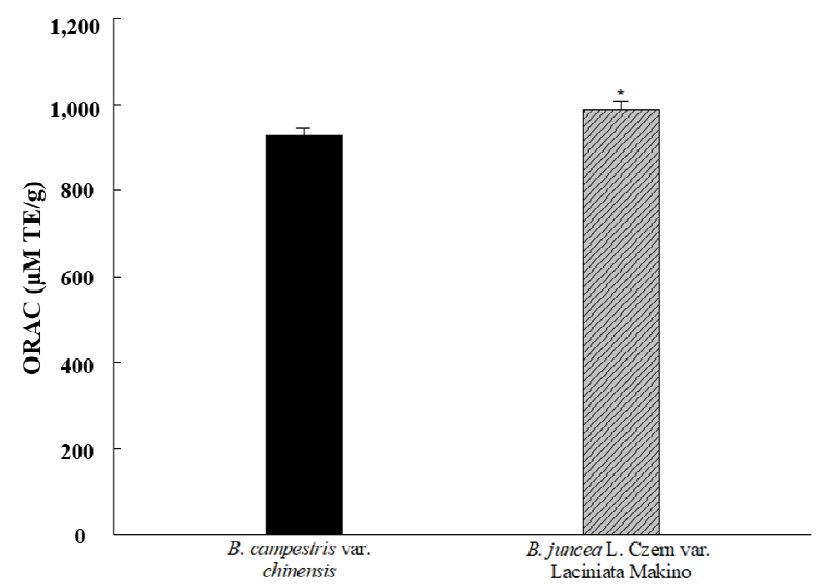

Fig. 4. ORAC value of Brassica spp. baby leaf extract. ORAC values expressed as Trolox equivalents ( $\mu \mathrm{M} \mathrm{TE} / \mathrm{g}$ ).

*Values are mean $\pm \mathrm{SD}(\mathrm{n}=3)$. *Values are significantly different between $B$. campestris var. chinensis and $B$. juncea $\mathrm{L}$. Czern var. Laciniata Makino $(\mathrm{p}<0.05)$.

\section{요 약}

본 연구에서는 청경채, 경수채 어린잎을 건강기능식품 소재로 활용 시 기초자료를 제공하고자 청경채와 경수채

Table 2. Chlorophylls and total carotenoid contents of Brassica spp. baby leaf extract

\begin{tabular}{ccccc}
\hline \multirow{2}{*}{ Sample } & \multicolumn{3}{c}{ Chlorophylls $(\mu \mathrm{g} / \mathrm{mL})$} & \multirow{2}{*}{ Total carotenoid contents $(\mu \mathrm{g} / \mathrm{mL})$} \\
\cline { 2 - 4 } & Total & $\mathrm{a}$ & $\mathrm{b}$ & $1.62 \pm 0.01^{*}$ \\
\hline B. campestris var. chinensis & $9.26 \pm 0.09^{1)}$ & $6.53 \pm 0.03$ & $2.72 \pm 0.07$ & $1.09 \pm 0.02$ \\
\hline B. juncea L. Czern var. Laciniata Makino & $6.48 \pm 0.11$ & $4.63 \pm 0.03$ & $1.85 \pm 0.08$ & \\
\hline
\end{tabular}

${ }^{1)}$ Values are mean \pm SD $(n=3)$.

*Values are significantly different between $B$. campestris var. chinensis and B. juncea L. Czern var. Laciniata Makino ( $\mathrm{p}<0.05)$.

\section{ORAC 지수}

ORAC 분석법은 peroxyl radical generator에서 유도된 peroxyl radical에 대한 항산화 물질의 저해능을 측정하는 방법으로 peroxyl radical과 형광 probe가 반응하여 형성되 는 비형광 생성물의 양이 시간에 따라 얼마나 감소하는지를 평가하여 항산화 활성을 측정하는 원리이다(31). 청경채와 경수채 어린잎 추출물을 이용한 ORAC 지수 측정 실험의 결과는 Fig. 4 와 같다. 청경채와 경수채 어린잎 추출물의
어린잎의 항산화 활성 및 성분을 규명하고자 수행되었다. 청경채와 경수채 어린잎 추출물을 이용하여 $\mathrm{DPPH}$ 라디칼 소거활성, $\mathrm{ABTS}$ 라디칼 소거활성, $\mathrm{FRAP}$ 활성, 총 페놀 함량, 총 클로로필 함량, 총 카로티노이드 함량 측정과 $\mathrm{ORAC}$ 지수 측정을 하였다. DPPH 라디칼 소거활성, $\mathrm{ABTS}$ 라디칼 소거활성, FRAP 활성 측정 결과 청경채와 경수채 어린잎 추출물 모두 농도 의존적으로 활성이 증가하는 것을 확인 할 수 있었다. 총 페놀 함량 측정 결과, 청경채와 경수 
채 어린잎 추출물에서 각각 $14.66 \pm 0.11,15.92 \pm 0.29 \mathrm{mg}$ $\mathrm{GAE} / \mathrm{g}$ 으로 측정되었다. 총 클로로필 함량 측정 결과, 청경 채 어린잎 추출물의 총 클로로필 함량은 $9.26 \pm 0.09 \mu \mathrm{g} / \mathrm{mL}$, 경수채 어린잎 추출물의 총 클로로필 함량은 $6.48 \pm 0.11 \mu$ $\mathrm{g} / \mathrm{mL}$ 이었다. 총 카로티노이드 함량 측정 결과 청경채와 경수채 어린잎 추출물에서 각각 $1.62 \pm 0.01 \mathrm{\mu g} / \mathrm{mL}, 1.09 \pm$ $0.02 \mathrm{\mu g} / \mathrm{mL}$ 로 청경채 추출물의 카로티노이드 함량이 높은 것으로 확인되었다. ORAC 지수를 측정한 결과 청경채와 경수채 어린잎 추출물 각각 $928.4 \pm 17.7,987.2 \pm 20.3 \mu \mathrm{M}$ $\mathrm{TE} / \mathrm{g}$ 의 값을 나타내었다. 본 연구의 실험 결과를 바탕으로 청경채와 경수채 어린잎의 항산화 기능성을 확인하고 생리 활성에 도움을 줄 수 있는 성분들의 함량을 측정함으로써 체내에서 산화적 손상에 대한 방어기전을 향상시키는 기능 성 식품의 소재로의 이용가능성을 확인하였다.

\section{감사의 글}

본 논문은 2017년도 한국연구재단 재원(NRF2017R1D1A3B06028469) 및 2018년 정부(교육부)의 재원 으로 한국 연구재단의 지원(한국연구재단-2018-미래기초 과학핵심리더양성사업/글로벌박사양성사업)을 받아 수행 하였으며 2015년도 강원 대학교 대학회계 학술연구조성비 로 연구하였음(관리번호-520150111).

\section{References}

1. Jung SW, Kim MK (2003) Effect of dried powders of chamomile, sage, and green tea on antioxidative capacity in 15-month-old rats. Korean J Nutr, 36, 699-710

2. Halliwell B, Gutteridge J (1984) Oxygen toxicity, oxygen radicals, transition metals and disease. Biochem J, 219, 1-14

3. Kuhn MA (2003) Oxygen Free Radicals and Antioxidants: An overview of how antioxidants protect the body from disease. Am J Nurs, 103, 58-62

4. Bokov A, Chaudhuri A, Richardson A (2004) The role of oxidative damage and stress in aging. Mech Ageing Dev, 125, 811-826

5. Steinberg D (1997) Low density lipoprotein oxidation and its pathobiological significance. J Biol Chem, 272, 20963-20966

6. Collier A, Rumley A, Rumley AG, Paterson JR, Leach JP, Lowe GD, Small, M (1992) Free radical activity and hemostatic factors in NIDDM patients with and without microalbuminuria. Diabetes, 41, 909-913
7. Kang S, Cho S, Chung JH, Hammerberg C, Fisher GJ, Voorhees JJ (2005) Inflammation and extracellular matrix degradation mediated by activated transcription factors nuclear factor- $\mathrm{kB}$ and activator protein-1 in inflammatory acne lesions in vivo. Am J Pathol, 166, 1691-1699

8. Rees MD, Kennett EC, Whitelock JM, Davies MJ (2008) Oxidative damage to extracellular matrix and its role in human pathologies. Free Radic Biol Med, 44, 1973-2001

9. Aruoma OI (1998) Free radical, oxidative stress and antioxidants in human health and disease. J Am Oil Chem Soc, 75, 199-212

10. Choe SY, Yang KH (1982) Toxicological studies of antioxidants buthylated hydroxytoluene (BHT) and buthylated hydroxyanisole (BHA). Korean J Food Sci Technol, 14, 283-288

11. Kyrtopoulos SA (1989) N-nitroso compound formation in human gastric juice. Cancer Surv, 8, 423-442

12. Kurilich AC, Tsau GJ, Brown A, Howard L, Klein BP, Jeffery EH, Juvik JA (1999) Carotene, tocopherol, and ascorbate contents in subspecies of Brassica oleracea. J Agric Food Chem, 47, 1576-1581

13. Soengas P, Sotelo T, Velasco P, Cartea ME (2011) Antioxidant properties of Brassica vegetables. Funct Plant Sci Biotechnol, 5, 43-55.

14. Kim JH, Park JH, Park SD, Choi SY, Seong JH, Moon KD (2002) Preparation and antioxidant activity of health drink with extract powders from safflower (Carthamus tinctorius L.) seed. Korean J Food Sci Technol, 34, 617-624

15. Re R, Pellegrini N, Proteggente A, Pannala A, Yang M, Rice-Evans C (1999) Antioxidant activity applying an improved ABTS radical cation decolorization assay. Free Radic Biol Med, 26, 1231-1237

16. Benzie IFF, Stranin JJ (1996) The ferric reducing ability of plasma (FRAP) as a measure of "antioxidnat power": the FRAP assay. Anal Biochem, 239, 70-76

17. Sato M, Ramarathnam N, Suzuki Y, Ohkubo T, Takeuchi M, Ochi H (1996) Varietal differences in the phenolic content and superoxide radical scavenging potential of wines from different sources. J Agric Food Chem, 44, 37-41

18. Wellburn AR (1994) The spectral determination of chlorophylls a and $\mathrm{b}$, as well as total carotenoids, using various solvents with spectrophotometers of different resolution. J Plant Physiol, 144, 307-313

19. Ou B, Hampsch-Woodill M, Prior RL (2001) Development and validation of an improved oxygen 
radical absorbance capacity assay using fluorescein as the fluorescent probe. J Agric Food Chem, 49, 4619-4626

20. Bondet V, Brand-Williams W, Berset C (1997) Kinetics and mechanisms of antioxidant activity using the DPPH. free radical method. LWT Food Sci Technol, 30, 609-615

21. Yang MJ, Cha SS, Lee JJ (2015) Effects of purple kohlrabi (brassica oleracea var. gongylodes) flesh and peel ethanol extracts on the antioxidant activity and antiproliferation of human cancer cells. Korean $\mathrm{J}$ Community Living Sci, 26, 405-414

22. Van den Berg R, Haenen GR, Van den Berg H, Bast A (1999) Applicability of an improved Trolox equivalent antioxidant capacity (TEAC) assay for evaluation of antioxidant capacity measurements of mixtures. Food Chem, 66, 511-517

23. Hwang ES, Kim GH (2011) Different cooking methods for Korean cabbage and their effect on antioxidant activity and carotenoid and tocopherol contents. Korean J Food Cookery Sci, 27, 713-721

24. Kim JH, Jeong CH, Choi GN, Kwak JH, Choi SG, Heo HJ (2009) Antioxidant and neuronal cell protective effects of methanol extract from Schizandra chinensis using an in vitro system. Korean J Food Sci Technol, 41, 712-716

25. Kim DB, Oh JW, Lee JS, Kim YH, Park IJ, Cho JH, Lee $\mathrm{OH}$ (2014) Antioxidant Activities of Green and Purple Kohlrabi Juices. Korean J Food Sci Technol, 46, 601-608
26. Folin O, Denis W (1912) On phosphotungsticphosphomolybdic compounds as color reagents. J Biol Chem, 12, 239-243

27. Chen HY, Yen GC (2007) Antioxidant activity and free radical-scavenging capacity of extracts from guava (Psidium guajava L.) leaves. Food Chem, 101, 686-694

28. Koh JH, Kim H, Hwang JH, Yu KW (2019) Anti-oxidative and Immunomodulating Activities of Solvent Extracts from Broccoli (Brassica oleracea) Sprouts. Korean J Food Nutr, 32, 1-10

29. Lee MH, Han JS, Nobuyuki K (2005) Changes of chlorophyll contents in Spinach by growth periods and storage. Korean J Food Cookery Sci, 21, 339-345

30. Ha JL, Bae JS, Park MK, Kim Y, Ha SH, Bae JM, Back K, Lee CH, Lee SW, Ahn MJ (2009) Quantitative analysis of carotenoids in carrot cultivars produced in Korea. J Environ Sci, 18, 1135-1141

31. Kurihara H, Fukami H, Asami S, Totoda Y, Nakai M, Shibata H, Yao XS. (2004) Effects of oolong tea on plasma antioxidative capacity in mice loaded with restraint stress assessed using the oxygen radical absorbance capacity (ORAC) assay. Biol Pharm Bull, 27, 1093-1098

32. Park HM, Hong JH (2014) Effect of extraction methods on antioxidant activities of Mori ramulus. J Korean Soc Food Sci Nutr, 43, 1709-1715 